\title{
Why Are the Skull-Bearers (Kāpālikas) Called Soma?
}

\author{
Judit Törzsök
}

\section{The Question}

The Kāpālikas or Skull-Bearers, who formed the third group of the Atimārga, alongside the Pāśupatas and the Lākulas, ${ }^{1}$ were perhaps the most notorious Saiva ascetics of classical India. They were known for their cremation ground rituals and for wandering around with a skull for an alms bowl. The skull (kapāla), their most conspicuous attribute, also provided their name. But the Kāpālikas are also designated as Somasiddhāntins, "Those of the Soma Doctrine,"2 or the "Soma People with the Skull."3 These appellations seem to have been of some importance because their initiation names also included or ended in -soma in most cases (e.g. Satyasoma, Devasomā, ${ }^{4}$ Somibhațāaraka ${ }^{5}$ ). What was this Somasiddhānta, doctrine of Soma or teaching about (the) Soma?

1 Concerning these distinctions within the Atimārga, the term Atimārga itself and the Kāpālikas as an Atimārgic group, see Sanderson 1988 and 2006. Professor Sanderson has published several ground-breaking papers focussing on the Kāpālikas. This paper, inspired by his discoveries, is dedicated to him.

2 This term figures in the Pauṣkaravrttti of Jñānaprakāśācārya, IF P transcript no. 11o, p. 591. They are also called "Knowers of the Doctrine of Soma" (somasiddhāntavedina h in Sarvajñānottara 14.4, edited by Goodall), which could be corrupt for somasiddhāntavādinah, "Those who Profess the Doctrine of Soma."

3 Or "Skull-Bearers Who are the Soma People," somajanakāpālī in Jayadrathayāmala 3.35.33c. There may be an attempt here to distinguish the skull-bearing Soma ascetics from other skullbearers, such as those who follow a Bhairava tantra or a Kaula tantra.

4 The names of the two Kāpālikas in the Mattavilāsaprahasana.

5 The name or title of a Kāpālika in the Kannada inscription of ancient Kolḷipāke, Andhra, in 1050 CE, cited by Lorenzen 1989, 233-234. This Kāpālika is said to be mukha-kamalavinirggata-Sōmasiddhāntābhiprāya- "devoted to the meaning of Somasiddhānta issued from the lotus mouth [?of Śiva]” (Lorenzen's translation). While this implies that the Somasiddhānta or Soma teaching was ultimately considered Śaiva revelation (if we accept Lorenzen's suggestion of supplying Śiva), it does not tell us anything about its nature and content, nor about the meaning of the word soma itself. The wording suggests, nevertheless, that it is not Śiva who is called Soma. 
In what way was it typical of Kāpālikas? Why did -soma figure in their initiation names?

I am afraid I will not be able to offer conclusive answers to most of these puzzling questions. However, I propose to look at a few passages about the Kāpālikas which may shed more light on what the word or name Soma possibly meant for them.

Now I am not the first to ask this question. An ingenious answer can already be found in commentaries on the Prabodhacandrodaya of Kṛ̣namiśra (itself dating from 1041-1073): commentators understand soma to mean sa-umā, i.e. "with/accompanied by Umā," with reference to the fact that a male Kāpālika normally had a consort, just as Śiva is accompanied by Umā. ${ }^{6}$

This understanding seems rather forced. Female Kāpālikas or tantric consorts are not normally called Umā and this interpretation does not seem to figure at all in earlier sources. It also fails to explain how we are to understand the element -soma in female initiation names (such as Devasomā), in which it cannot mean "with Umā/with a female consort." Nevertheless, the sa-umā explanation of soma higlights an important trait of the Kāpāilikas, namely that they were exceptional in the Atimārga in that male and female initiates performed rituals together ${ }^{7}$ and were obviously not required to maintain celibacy, unlike (most probably) the ascetics of the Pāśupata and Lākula groups.

David Lorenzen has proposed a different hypothesis. ${ }^{8}$ He identified a Kāpālika called Kāpāli-śarman in a (probably) sixth century inscription from Karnataka. This Kāpāliśarman is said to have performed vedic Soma sacrifices. Lorenzen therefore suggests that Kāpālikas were perhaps dedicated vedic Soma sacrificers.

This is also rather unlikely, for at least two reasons. First, Kāpāliśarman may not have been a Kāpālika in the strict sense, for his name does not include Soma and does not appear to conform to other kinds of Kāpālika names either. ${ }^{9}$ Second, nowhere else is it said that Kāpālikas performed vedic Soma sacrifices. However, as we shall see they took interest in particular 'essences' other than the vedic Soma, and in a metaphorical sense, perhaps did perform their own kind of Soma ritual.

6 For this and some other references to Kāpālikas associated with some Soma doctrine, see Lorenzen 1991, 83 .

7 Two well-known literary examples are the Kāpālika man with his partner in the Mattavilāsaprahasana and the Kāpālika couple in the fifth act of Bhavabhūti's Mālatīmādhava.

8 Lorenzen 1989, 235 citing K.V. Ramesh Inscriptions of the Western Gangas 70-74, no. 19, inscription from Bangalore district, 6th cent.? (sic!).

9 Since Kapālin/Kāpālika can denote Śiva/Bhairava himself, the name could simply mean "Protected by Śiva/Bhairava" without being markedly Kāpālika. 
We reach firmer ground when we turn to the often-cited Malhar or Junwani copper plate inscription (647 CE, see Bakker 2000 and 2015; Sanderson 2012), which lists a lineage of Kāpālikas as identified by Sanderson. This mentions Somaśarman and the "line of tradition starting with Soma" (continuing later with Rudrasoma, Tejasoma, Bhimasoma). It is in Somaśarman's house that Lakulīśa, founder of the Pāsupata order, is said to have been born as an incarnation (avatāra) of Śiva. Lakulīśa was then initiated into or through the mahāvrata, perhaps by Somaśarman himself:

[...] adhunā kali-kālam āsādya śrimmal-Lakulīśa-nātho vatīrya Somaśarmākhya-brāhmaṇa-kule jātah mahāvrate[ te?]na dīkșito jagad-indus tenāpi Musalīśas tatah Somādi-pāramparya-krameña sthānaguru-śri-Rudrasoma-praśisya-śri-Tejasoma-śisyebhyah śrīmad-Bhìmasoma-pādebhyah [...]

mahāvrate[ te]na ] conj. Isaacson; mahāvratena
Musalīśas ] conj. Sanderson; mugalíśas
sthānaguru ] conj. Majumdar; sthāne guru

[...] reaching the present Kali age, the venerable Lord Lakulīśa took up an incarnation and was born in the family of a brahmin called Somaśarman. He was initiated into the Great Observance by him (?) [and became] the Moon of the World. Then by him, Musalissa [was initiated], then, by the unbroken tradition starting with Soma, the local Master Rudrasoma, his disciple Tejasoma, whose pupil is the venerable Bhīmasoma [...]

Before examining the question of Soma and related issues, I would like to point out some details concerning the word mahāvrata or Great Observance. Lakuliśa and others were most probably initiated into the mahāvrata (mahāvrate) and not with/by the mahāvrata (mahāvratena), for this observance is not known to be used as a rite of initiation in any Śaiva system. ${ }^{10}$

By the beginning of the seventh century, the mahāvrata certainly referred to the ritualized mimesis of Śiva's expiation for cutting off Brahmā's fifth head.

10 This follows the conjecture proposed by Isaacson, although the reading of mahāvratena is of course grammatically acceptable. However, it is also possible that the instrumental mahävratena was understood to stand for the locative, and that no additional instrumental tena was intended. In this case, it is not expressed that Somaśarman initiates Lakulīśa, although it may again be implied. Bakker $(2015,143)$ opts for the instrumental, but assumes that this only implies a Pāśupata affiliation of Lakulīśa. 
According to this well-known story, Śiva must wander with a skull he uses as an alms bowl, for he has committed the sin of killing a brahmin, i.e. Brahmā. Wandering with a skull for twelve years is in fact the expiatory observance for killing a brahmin as prescribed in the Dharmasūtras, ${ }^{11}$ but there it is not yet called mahāvrata. Although most attestations of the mythological story come from late puranic sources, the myth already figures in the (original) Skandapurāna (chapters $\left.5^{-7}\right),{ }^{12}$ dated around the end of the sixth and beginning of the seventh century.

Moreover, the Kāpālika Satyasoma in the Mattavilāsaprahasana (6oo$625 \mathrm{CE}$ ) mentions that it was thanks to the practice of the mahāvrata that his Lord bearing the crescent moon on his head was purified of his sin, which he had committed by cutting Brahmā's head..$^{13}$ The verse clearly identifies Śiva's mahāvrata as the expiation rite for a brahmin slayer, and also shows that Kāpālikas were practising the mahāvrata in imitation of Śiva. In fact, the Skandapurạna (6.5-6) also seems to associate this observance with sanguinary practices, such as those of the Kāpālikas. For when Śiva-Nīlalohita starts looking for suitable alms, Viṣnu tries to fill his kapăla-bowl with his own blood—a very odd, distinctively Kāpālika notion of what alms should consist of.

Now returning to the question of the Soma lineage: Lakulīsa, whether he was indeed initiated by Somaśarman or not, is said to have been born in Somaśar-

11 See e.g. Baudhāyanadharmasūtra 2.1.2-3: bhrūnahā dvādaśa samāḥ kapālì khațvāngì gardabhacarmavāsā aranyaniketanah śmaśāne dhvajaṃ śavaśirah krtvā kuțị̣̄ kārayet | tām āvaset | saptāgārāṇi bhaikșam caran svakarmācakșāṇas tena prāṇān dhārayet |. "A man who has killed a learned Brahmin should do the following for twelve years. He should carry a skull and a post from a bed-frame; wear the skin of an ass; reside in the wilderness; and, using the head of a corpse as his flag, get a hut built in a cemetery and live in it. He should maintain himself by begging almsfood from seven houses while proclaiming his crime." Translation by Olivelle (2000, 241). See Gautamadharmasūtra 22.4: khațāangakapālapāninir vā dvādaśa saṃvatsarān brahmacārī bhaikșāya grāmaṃ praviśet | karmācakșānah. "Or else, for twelve years he should live a chaste life and, carrying the post from a bed-frame and a skull, enter a village only to beg for food while proclaiming his crime." Translation by Olivelle $(2000,175)$, who remarks in the notes to this passage that khațānga must mean skull-staff (a staff topped with a skull) rather than the post of a bed-frame. Brick 2012, however, shows convincingly that the post of a bed-frame was probably intended at the time of the Dharmasūtras. See also Yãjñavalkyasmrti 3.243: śirahkapālī dhvajavān bhikṣāśí karma vedayan | brahmahā dvādaśābdāni mitabhukśuddhim äpnuyāt $\|$.

12 The version related here replaces the figure of Śiva with one of his ectypes, Nilalohita. On this narrative device, which is used here to distance the supreme deity from sanguinary practices, see Granoff 2006.

13 17ab: āsthāya prayato mahāvratam idam bālenducūḍāmaṇiḥ, svāmī no mumuce pitāmahaśiraśchedodbhavād enasah |. 
man's house. According to the inscription, the Kāpālikas belong to the spiritual lineage starting with Soma, and their initiation names therefore seem to be derived from the founder's name. The name Soma can naturally be understood as a short form of Somaśarman. Thus, Kāpālikas are the Soma people because they follow the tradition started by Somaśarman.

Our investigation could stop here. For the name Soma seems to be sufficiently explained in this way. However, several issues remain unexplained. It is not clear whether Somaśarman was a historical person. If he did exist, it still remains uncertain whether he was indeed the founder of the Kāpālika movement or whether Kāpālikas claimed retrospectively that he was their founder. Thus, we cannot take it for granted that the Soma name indeed derives from him.

For this reason, I suggest we look at some other details more closely. Lakulīśa, after his initiation in Somaśarman's house, is called the Moon of the Word ( jagadindu) in the inscription. There are at least three interpretations of jagadindu:

1. A natural understanding of the moon as having cool rays. Thus, "Moon [whose cooling rays have calmed the fever] of the world" (translation by Sanderson 2012).

2. Moon on the earth, i.e. having a lunar-white body (sitänga) on account of the bathing with ashes (Bakker 2000; 2015, 153). This understanding is backed up by the description of Lakulīsa in the Skandapurāna as being white-bodied when covered with ashes. ${ }^{14}$

3. Without going against either of these interpretations, both of which are plausible, I propose as a tentative hypothesis that, in addition, the expression jagadindu may indirectly allude to a Kāpālika affiliation if we understand this in the sense of *Jagatsoma, a compound suggestive of a Kāpālika initiation name. ${ }^{15}$ This may imply two things. First, it is possible that

14 It must also be noted that the Skandapurāna (180.10) calls the mere ash-bath a/the great observance (mahāvrata). It also says that Somaśarman with his family received Lakulísa's grace when he visited them in their house, and that they were given yogasiddhi (167.125 ff.). The Skandapurāna appears to represent an earlier(?)/pāśupata version of the story. (Cf. also Bakker 2015, 143 ff.) Bakker 2015, 143-144 (note 442) also proposes that the Soma name suggests a parallel with the Soma-vamśa dynastic affiliation of Mahāśivagupta. However, the Soma name figures elsewhere, in seventh-century South India in the names of Kāpālikas of the Mattaviläsaprahasana, where no such parallel can be assumed; such implications therefore seem unlikely.

15 I cannot cite any initiate with this name, and I do not intend to suggest that Jagatsoma (or Jagadindu) was necessarily an actual initiation name. The word may, nevertheless, be construed in the same manner as Kāpālika initiation names such as Satyasoma, Devasoma, 
the Kāpālikas derive their name Soma/Moon from Lakulīsa, too, who is considered the Moon of the World. Second, the sequence of events as presented in the inscription may also suggest that Lakuliśa himself came to be called the "Moon of the World" (suggestive of a Kāpālika initiation name) because of Somaśarman. Whatever is the case, the lunar image is emphatically present in the names or epithets of both alleged founders as well as in the initiation names of Kāpālikas.

Now the naming of Lakulissa as the "Moon," in the manner of a Kāpālika, may be more than a coincidence. It may well be understood as an attempt to present Lakulīśa as a true Kāpālika, perhaps via his association with another "Moon person," Somaśarman. Or, from another point of view, by presenting Lakulīśa as a Kāpālika initiate, the text may suggest the preeminence of the Kāpālikas over the other two Atimārga groups, the Pāsupatas and the Lākulas.

But no matter how we understand the hidden agenda of the above inscription (if there is one), it is undeniable that the Kāpālikas' initiation name ending in -soma is understood to recall both their founder(s)' name and the image of the moon.

\section{The Moon and the Nectar of Immortality (amrta) in the Skull(s)}

The moon also forms an important element of Pāśupata yogic practices. As we learn from the Skandapurāna (179.28ff.), as pointed out by Bakker $(2015,141)$, their "accomplishment in yoga" (yogasiddhi) comes about through a process of withdrawing the senses until the practitioner can see a lunar disc (somamandala) in his heart. From the moonlight within his body, yogic powers, omniscience and the like arise. These powers include being immune to disease (vyädhayo nāviśanty enam) and possessing a divine body (divyam vapuh).

Speaking of the moon and practices related to its visualization, the Kāpālikas appear to share the pan-Indian idea that it also contains the nectar of immortality. ${ }^{16}$ In one passage of Bhavabhūti's Mālatīmādhava (5.23) an invocation is addressed to the fierce goddess, Cāmuṇ̂a, which describes her violent tāṇạva dance. The verse is uttered by the two Kāpālikas in the cremation ground. During this dance, the goddess inadvertently slashes the moon, from which the

etc., which can be interpreted as "Moon of Truth," "Moon of the Gods," etc. What I propose is that this parallelism of names ending with "-moon" seems too remarkable to be accidental.

16 This idea perhaps also contributed to the spread of various visualization practices centered around the image of the moon. 
amrta flows downward and fills her garland of skulls. The skulls, thus resurrected, start emitting a loud and harsh laughter. ${ }^{17}$

This image is not particularly significant in itself. However, it seems that Kāpālikas were particularily interested in a special sort of ambrosia. In their quest for the amrta, they probably joined a large range of ascetics or yogins of the period who, in various ways and through different practices, all sought the same magical essence. ${ }^{18}$ So what exactly was the amrta of the Kāpālikas and how did they expect to find or produce it?

What is the Kāpālikas' Nectar (amṛta/soma)?

We now turn again to the Kāpālikas of the Mālatīmādhava. ${ }^{19}$ At one point in the story (5.2), the female practitioner mentions that she can extract the socalled "five nectars" ( pañcämrta), which are five vital essences of the human body. They have a powerful, invigorating effect (as one would expect from such a nectar), so much so that the female Kāpālika can fly a great distance in a few seconds.

17 pracalita-kari-krtti-paryanta-cañcan-nakha-äghāta-bhinnendu-nị̣syandamānāmrta-

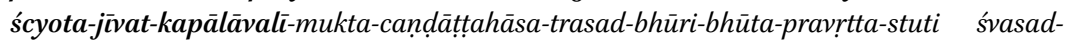
asita-bhujaṃga-bhogāingada-granthi-nișpīdana-sphāra-phullat-phaṇā-pīṭa-niryad-vișajyotir-ujj̣mbhaṇoḍ̂amara-vyasta-vistāri-doh-khaṇda-paryāsita-kșmādharam | jvaladanala-piśanga-netra-cchațācchanna-bhīmottamānga-bhrami-prastutālāta-cakra-kriyāsyūta-dig-bhāgam uttuñga-khațvāinga-koți-dhvajoddhūti-vikșipta-tārā-gaṇam pramuditakațapūtanottāla-vetāla-tāla-sphuțat-karṇa-saṃbhrānta-Gaurī-ghanāśleșa-hrșyan-manas-Tryambakānandi vạ̣ tāṇ ḍvam devi bhūyād abhịștyai ca hrștyai ca nah |.

18 Obtaining the nectar of immortality and, thanks to it, an immortal physical body is the main goal of the hațhayogic and Nath yogic traditions; see Mallinson 2007 and Ondračka 2007. Mallinson $(2015,120 \mathrm{ff}$.) proposes that there may have been an early, nonsectarian tradition of ascetics, the precursor of what is later known as hathayoga, for which he finds traces already in the Pali Canon.

19 I understand, in the context of this paper, the Kāpālikas of this play to represent the Kāpālikas of the Atimārga here under discussion. They could alternatively be considered skull-bearing tantric practitioners, as Hatley $(2007,143 \mathrm{ff}$.) argues on the basis of numerous parallels with prescriptions found in the Brahmayamanala and elsewhere. In fact, one could interpret the evidence in two ways: either take the Kāpālikas of the play to belong to the Atimārga, which has strong influence on later Śaiva tantras of the Vidyāpiț̣̣a, or one can take them to be tantric skull-bearers of the Vidyāpițha, who certainly inherit much from the Kāpālikas of the Atimārga. In either case, the practices described in the play may well reflect what is a ritual core common to both the Kāpālikas of the Atimārga and those of the Vidyāpițha. For this reason, in the context of the present argument, I understand the Mālatīmādhava's Kāpālikas to be representative of Atimārga Kāpālikas or their practices, even if this identity remains uncertain. 
The extraction of the five nectars (pañcāmrtākarșaṇa), as well as other, Kāpālika-type cremation ground practices, also figure in the Brahmayāmala, as Hatley $(2007,143 \mathrm{ff}$.) points out. The five substances are not listed in a systematic way, but they usually seem to include these four: semen (śukra), blood (rakta), fat/marrow (medas) and sneha (see also the entry pañcāmrta in Tāntrikābhidhānakośa, vol. III). Other sources also describe Kāpālikas as making use of various parts of the human body. Kāpālikas use human flesh (mahāmāmsa), brain (mastișka), intestines (antra), fat (vasā) and blood (kìläla) in ritual, and drink alcohol (surā), according to Prabodhacandrodaya 3.13.

In addition to the extraction of the five nectars, the Brahmayamala also includes rituals which make particular use of human body parts and are to be performed in the cremation ground. A notable series of chapters prescribing such rites forms a small cluster around chapter 46 . Since the practices prescribed have close affinity to the kinds of ritual attributed to Kāpālikas, these chapters could well be adaptations or assimilations of originally Kāpālika rituals, ${ }^{20}$ although this remains a hypothesis in the absence of any surviving Kāpālika scriptures. It is also notable that the Brahmayammala describes possession (āveśa) by Bhairava, stating that through possession one obtains Bhairavahood; and possession was, according to numerous Śaiva sources about the subject, the way in which Kāpālikas claimed to attain final liberation. ${ }^{21}$

Now in chapter 46 of the Brahmayāmala, much like the Kāpālikas, the practitioner makes ritual use of human flesh, hair (keśa), bones (asthi), body fluids (picu), particularly blood (rakta), and intestines (antra); moreover, he offers and drinks alcohol (madirā).

It is in this chapter that the amrta comes to fore again in ritual. For the main subject here is amrtamanthana, the churning and drinking of the amrta. The Sādhaka is to make pots from clay obtained from the cremation ground, contruct a sacrificial pavilion from bones, and place the ritual cauldron upon a corpse. He is required to churn a mixture including mahäpicu (sexual fluids or various other human fluids?) using a piece of bone as the churning stick, with a rope made of human hair, intestines and skin (?). The cauldron is identified with Aghorī and the churning stick with Bhairava. In this rite, the Sādhaka re-enacts the cosmic churning of the ocean, and the same miraculous objects emerge (the Kaustubha gem, etc.) as the gods brought forth during the primordial churning. Then the terrifying goddess, Canḍikā, receives

$20 \quad$ For more arguments, see Törzsök 2011 and 2015.

21 On this, see e.g. Sanderson 2009, 133 note 311. 
homage. She appears in the form of Aghorī, offering the Sādhaka a boon. The practitioner chooses to drink the milk of Aghorìs breasts. The chapter ends by saying that having produced the amrta and having drunk left and right (probably meaning having drunk Aghorìs milk from both breasts), one becomes omniscient, Bhairava himself. Although Aghorìs milk and the amrta that the Sādhaka prepares are not identified, they could well be the same thing. ${ }^{22}$

22 The following working edition is based on Shaman Hatley's transcription of the old palmleaf manuscript. Only the relevant verses are given here: mahāpicususampūurnạ̣ kuryāt sthāliṃ śavopari $\|44\|$ àyatasya tu nalakam mahā-m-asthi śavopari eșa manthānako devi asmin tantre praśasyate ||45|| keśeșu netrakam kuryād antraih karttrvimiśritaih | (karttr in the sense of krtti??) navahastam susampūūnam vidyāmālāniyojitam $\|46\|$ suviśuddhamahībhāgam rajasampātaśobhitam | mahāsthālì tu pārśve tu evam kṛ̂ā mahātape $\|47\|$ Aghoryā sthālirūpām tu dhyāyen mantrī suśobhanām | śaktisthām śaktirūpām ca dhyāye somātmake sthitām $\|48\|$ Manthānabhairavam devam śuddhasphațikanirmalam | sahasrabhujaparyantam cinten manthānarūpinam ||49|| -.. mahāmanthāna kurvīta yam sthitvā tu Śivo bhavet $\|61\|$ -.. namaskṛtvāsurị̄n divyām tatah sādhanam ārabhet ||62|| ... evaṃ mālais tu tāṃ dīptāṃ dhyātvā manthānamandiram | netrakam ca tathaiveha cintayed Vāsukirūpinam ||66|| kșīrodam sthāpayet sthāli ātmà bhairavarūpinam | pūjayitvā tu manthānam prakșipet sthālimadhyatah ||67|| ... kșaṇamātram mathed yāvac chaśänkottișthate priye ||92|| Kaustubham ca tato tișthe vimānam Puṣpakam tathā| evam ādyāni siddhīni pūrvaśāstreṇa bhāṣitāọm ||93\| uttișthati mahābhāge śataśo ['] tha sahaśraśah | (mahābhāgo Ms.)

...

kșaṇamātram mathed yāva namaskrtvā tu Caṇdikām | tatrottișțhati vai devi Aghorī siddhidāyikā ||1०7||

$\cdots$ sādhakovāca \| yadi tuștāsi māṃ devi stanaṃ me dada Ambike ||114\| śrutvā vākyam tato devyām sādhakasya suśobhanam | ehi ehi mahāsattva stana me piba putraka\{h\} ||115\| tvam muktvā tu mahāsattva $\{h\}$ ko [']nyo putratvam arhati | parișvajya tato vīraṃ stanaṃ dadāmi sādhaka\{ḩ\} ||116\| 
What emerges from this chapter is that the preparation of the nectar of immortality was also an important way in which one could obtain Bhairavahood. Moreover, it involved worship of a fearsome goddess, Caṇịikā or Aghorī, which again recalls the Kāpālikas in the Málatìmādhava, who worship Cāmuṇ̣ā.

But was the bodily amṛta the only nectar the Kāpālikas collected and consumed?

\section{$5 \quad$ Alcohol, Immortality and Soma}

The Kāpālikas were also known for their use of alcohol in ritual. The Prabodhacandrodaya (3.20 and prose) presents a Kāpālika rite of initiation, in the course of which the Kāpālika offers alcohol to the initiands and calls it amrta, for, once again, this releases someone from the bondages of this world and of the state of being a bound soul. In this sense, amrta is not just a simple metaphor denoting a precious or delicious liquid. It is a genuine nectar of immortality, for it actually makes one immortal by bestowing final release, $m o k s ̦ a .^{23}$

In a more satirical way, the Kāpālikas' alcohol is also treated as their equivalent to the vedic Soma. The Kāpālika in the Mattavilāsaprahasana cries out as follows when he sees a pub:

My darling, look. This pub resembles the vedic sacrificial ground. For its signpost resembles the sacrificial pillar; in this case alcohol is the Soma, drunkards are the sacrificial priests, the wine glasses are the special cups for drinking Soma, the roasted meat and other appetizers are the fire oblations, the drunken babblings are the sacrificial formulae, the songs are the Sāman-hymns, the pitchers are the sacrificial ladles, thirst is the fire and the owner of the pub is the patron of the sacrifice. ${ }^{24}$

evam krtvāpi vai devi -m- amrtam sādhakottamah |

savyāsavyam tato pītvā sarvajño bhavate kṣaṇāt ||120|| (kṣaṇām Ms)

bhairavo ['] tha svayam sākșā guhyakānām prabhu[r] bhavet | (prabhu Ms unmetr.)

(Superfluous visargas are placed between curly braces. Square brackets indicate editorial additions. Comments and variants are in parentheses. A hiatus-filling $m$ is printed as - $m-$.)

Śraddhā: bhaavaṃ, sulāe pūlitam bhāanaṃ [= bhagavan, surayā pūritaṃ bhājanaṃ].

Kāpālikaḥ (pītvā, śeșaṃ bhikṣukṣapaṇakayor arpayati):

idạ̣ pavitram amṛtạ̣ pìyatām bhavabheșajam |

paśupāśasamucchedakāraṇạ̣ Bhairavoditam \|20||.

24 Kapālī: priye! paśya paśya | eșa surāpaṇo yajñavāțavibhūtim anukaroti | atra hi dhvajastambho yūpaḥ, surā somaḥ, śauṇ̣̂a rtvijaḥ, caṣakāś camasāḥ, śūlyamāmsaprabhṛtaya 
Nobody would assume from this passage that the Kāpālikas were Soma sacrificers - the comic effect intended is readily evident. It is nevertheless interesting that, once again, the Kāpāilikas are presented as having a special nectar of their own, whether it is called amrta or Soma, and that the ritual significance of this nectar may be, it seems, comparable to the Soma of vedic ritual.

Inventors of a New Nectar (soma/amrta)? Or Simply 'the Best?'

From the passages looked at here, no firm conclusion can be drawn as to why the Kāpālikas included the word Soma in their initiation names and what exactly they meant by "the teaching of or about Soma" (Somasiddhānta). The most readily explicable case is found in the Junwani copper plate inscription, which associates the Soma name with the name of their alleged founder, Somaśarman. It is, nevertheless, possible that Kāpāilikas identified Somaśarman as their founder only retrospectively and that this derivation of Soma from Somaśarman is secondary.

Conveniently, Soma as a proper name is also one of Śiva's names, ${ }^{25}$ although it does not necessary imply that he is accompanied by Umā $(s a-u m \bar{a})$. Soma is probably used metaphorically for Śiva, just as it is used for other gods such as Viṣnu or Kubera. In any case, somasiddhānta can accordingly simply mean "Śiva's doctrine." However, as a rather generic appellation of the god's teaching, it seems unlikely to designate the Kāpālika doctrine in particular.

Soma, meaning "moon," and more particularly the nectar of immortality the moon is supposed to contain, is another possible explanation. Various kinds of nectar (amrta/Soma), whether alcohol or essences of the human body, appear to be in the focus of attention in Kāpālika rituals. The vital essences in particular were considered to have an invigorating effect that provided Kāpālikas with the magical power they were apparently famous for. Concoctions of the vital essences were probably thought to bestow omniscience and Bhairavahood. Whether it was really this nectar or these nectars that were at the origin of the name Soma is impossible to tell; but whatever the case may be, the bodily nectar of the vital essences was most probably a crucial element of Kāpālika doctrine and practice. ${ }^{26}$

upadaṃśa havirviśeșāh, mattavacanāni yajūmș̣i, gītāni sāmāni, udañkāh sruvāḥ, tarșo 'gnịh, surāpanāāhipatir yajamānaḥ|.

25 See e.g. Skandapurāṇa 2.3, 29.103, Kathāsaritsāgara 7.1.101.

26 This may not be sufficient to explain what was meant by their "doctrine of/about Soma," 
Given this rather wide range of possibilities, it is possible that the Kāpālikas themselves intended to make full use the natural polysemy of the word Soma, although it is less likely that such polysemy was intended from the very beginning.

Finally, to add one more possible interpretation: Soma at the end of a compound can also mean "chief, principal, the best."27 In this sense, one could understand the Kāpālika names to imply that they considered themselves simply the best Śaivas around.

\section{Acknowledgements}

I would like to thank all the participants of the Symposium Saivism and the Tantric Traditions held in honour of Professor A.G.J.S. Sanderson for their questions, comments and criticism concerning the first version of this paper, in particular Professor Sanderson and Professor Bakker. I am also indebted to Csaba Kiss and Shaman Hatley for comments on and corrections of the final draft. The written version of the paper reproduces some aspects of the oral presentation stylistically.

\section{References}

\section{Primary Sources}

Kathāsaritsāgara of Somadeva[bhațta]. Pandit Durgaprasad and Kashinath Pandurang Parab, eds. Revised by Wasudev Laxman Shastri Panshikar. Bombay: Nirnay Sāgar Press, 1930.

Gautamadharmasūtra. See Olivelle 2000.

Jayadrathayāmala. National Archives, Kathmandu ms. nos. 5-465o (șațka 1 and 2); 5722 (șațka 3); 1-1468 (șațka 4, NGMP reel no. A151-116). Electronic text provided by Olga Serbaeva. I am grateful to Dr. Serbaeva for making her transcription available to me.

Pauṣkaravrttti of Jñānaprakāsaācārya. IFP T. no. 110. Electronic text of the Muktabodha Indological Research Institute, https://etexts.muktabodha.org/digital_library.htm.

Prabodhacandrodaya of Kṛṣnamiśra. Armelle Pédraglio, ed. and trans. Le Prabodhacandrodaya de Krșnamiśra Paris: de Boccard, 1974.

Baudhāyanadharmasūtra. See Olivelle 2000.

but such "doctrine" was not necessarily an abstract theory. The word siddhānta may be used in the sense of "teaching" rather than "philosophy" or "philosophical conclusion."

For this meaning, see Apte 1957, entries on soma and nrsoma. 
Brahmayāmala. National Archives, Kathmandu Ms. No.3-37o. Electronic text provided by Shaman Hatley. I am grateful to Dr. Hatley for making his transcription available to me.

Mattavilāsaprahasana of Mahendravikramavarma. T. Gaṇapati Śāstrī, ed. Trivandrum: Rājakīya Mudraṇayantrālaya, 1917.

Mālatīmādhava of Bhavabhūti. M.R. Kale, ed. Mālatīmādhava of Bhavabhūti with the Commentary of Jagaddhara. Delhi: Motilal Banarsidass, 1996. (1st ed. 1928.)

Sarvajñānottara. Dominic Goodall, ed. Draft edition based on IFP Ms. T.334, IFP Ms. T.76o and NAK Ms. 1-1692 and 3 printed editions. I am grateful to Dominic Goodall for making his edition available to me.

Yãjñavalkyasmṛti of Yājñavalkya. Narayan Ram Acharya, ed. Yājñavalkyasmṛti of Yogissvara Yãjñavalkya, with the Commentary Mitākșara of Vijñāneśvara. Bombay: Nirnayasagara Press, 1949.

Skandapurāṇa. R. Adriaensen, H.T. Bakker and H. Isaacson, eds. Skandapurāṇa, vol. I. (Adhyāyas 1-25). Critically Edited with Prolegomena and English Synopsis. Supplement to Groningen Oriental Studies. Groningen: Egbert Forsten, 1998.

Skandapurāṇa. Kṛṣnaprasāda Bhaț̣arāī, ed. Skandapurāṇasya Ambikākhaṇdaḥ. Mahendraratnagranthamālā, no. 2. Kathmandu: 1988.

\section{Secondary Sources}

Apte, V.S. 1957 [1998]. The Practical Sanskrit-English Dictionary. Revised and enlarged edition. Reprint (3 vols. in 1), Kyoto: Rinsen Book Company.

Bakker, Hans T. 20oo. "Somaśarman, Somavaṃśa and Somasiddhānta: A Pāśupata Tradition in Seventh-Century Dakṣiṇa Kosala." In Harānandalaharī: Volume in Honour of Professor Minoru Hara on his Seventieth Birthday, edited by Ryutaro Tsuchida and Albrecht Wezler, 1-19. Reinbek. Dr. Inge Wezler Verlag für Orientalistische Fachpublikationen.

Bakker, Hans T. 2015. The World of the Skandapurāna-Northern India in the Sixth and Seventh Centuries. Leiden; Boston: Brill.

Brick, David J. 2012. "The Origin of the Khațvānga Staff." Journal of the American Oriental Society 132 (1): 31-39.

Granoff, Phillis. 2006. "Śiva and His Ganas: Techniques of Narrative Distancing in Purānic Stories." In Voice of the Orient (A Tribute to Prof. Upendranath Dhal), edited by Raghunath Panda and Madhusudan Mishra, 77-103. Delhi: Eastern Book Linkers.

Hatley, Shaman. 2007. The Brahmayāmala and Early Śaiva Cult of Yoginīs. Ph.D. thesis, University of Pennsylvania.

Lorenzen, David N. 1991 [1972]. The Kāpālikas and Kālamukhas: Two Lost Śaivaite Sects. 2nd edition. Delhi: Motilal Banarsidass.

Lorenzen, David N. 1990 [1989]. "New Data on the Kāpālikas." In Criminal Gods and 
Demon Devotees: Essays on the Guardians of Popular Hinduism, edited by Alfred Hiltebeitel, 231-238. Reprint, New Delhi: Manohar.

Mallinson, James. 2007. The Khecarīvidyā of Ādinātha. A Critical Edition and Annotated Translation of an Early Text of Hațhayoga. London; New York: Routledge.

Mallinson, James. 2015. "Śāktism and hațhayoga." In Goddess Traditions in Tantric Hinduism - History Practice and Doctrine, edited by Bjarne Wernicke-Olesen, 109-140. London; New York: Routledge.

Olivelle, Patrick. 200o. Dharmasūtras. The Law Codes of Āpastamba, Gautama, Baudhāyana and Vasiștha. Delhi: Motilal Banarsidass.

Ondračka, Lubomir. 2007. "Perfected Body, Divine Body and Other Bodies in the NāthaSiddha Sanskrit Texts." Pre-print version of a paper presented at the 13 th World Sanskrit Conference. Available on the author's page at www.academia.edu.

Sanderson, Alexis G.J.S. 1988. "Śaivism and the Tantric Traditions." In The World's Religions, edited by S. Sutherland, L. Houlden, P. Clarke and F. Hardy, 66o-704. London: Routledge.

Sanderson, Alexis G.J.S. 2006. "The Lākulas: New Evidence of a System Intermediate between Pāñcārthika Pāśupatism and Āgamic Śaivism." Indian Philosphical Annual 24: $143^{-217}$.

Sanderson, Alexis G.J.S. 20o9. "The Śaiva Age.” In Genesis and development of Tantrism, edited by Shingo Einoo, 41-350. Tokyo: Institute of Oriental Culture, University of Tokyo.

Sanderson, Alexis G.J.S. 2012. "Śaivism and Brahmanism. All Souls, Hilary Term 2012." Lecture handout available on the author's page at www.academia.edu.

Tāntrikābhidhānakośa. Dictionnaire des terms techniques de la littérature hindoue tantrique. A Dictionary of Technical Terms from Hindu Tantric Literature. Vol. III. Dominic Goodall and Marion Rastelli, eds. Beiträge zur Kultur- und Geistesgeschichte Asiens, no. 76. Vienna: Austrian Academy of Sciences Press, 2013.

Törzsök, Judit. 2011. "Kāpālikas." In Brill's Encyclopedia of Hinduism, vol. III, edited by Knut A. Jacobsen, et al., 355-361. Leiden: Brill.

Törzsök, Judit. 2015. "The (Un)Dreadful Goddess: Aghorī in early Saākta tantras.” In Goddess Traditions in Tantric Hinduism: History, Practice and Doctrine, edited by Bjarne Wernicke-Olesen, 33-5o. London; New York: Routledge. 